\title{
MEASURING CONTRIBUTION TOWARDS BRAND LOVE AND EFFECT OF BRAND LOVE ON WOM: EVIDENCE FROM CONSUMER DURABLE GOODS
}

\author{
Aarzoo Waseem and Fatima Laraib
}

\begin{abstract}
Brand love is supposed to most important key intents in the brand management and consumer is the imperative assets to the organization this study is a pervasive study for the companies and institutions plus brand love contribute itself to gratify consumer satisfaction in (SMCG) sector and consumer make their trust on reliable brands and this factor increase the goodwill of brands. This specific study has also research has also with several limitations due to the time limitations other researchers will have a chance to find other dimensions with a source of new variable as psychological behaviour of the consumers in FMCG zone. Furthermore, the value of brand love supportive to managers that pursuing the expansion of brand love is acceptable. The consequences of this research are expected results brand trust, attitude and image all have major contribution to make brand love and it offers direction and inspires the consumer and customer to make out the elements of the greater love of brands. The sample size for the study is 384 respondents \& analysis was made through SPSS and Smart PLS to identify the outcomes of brand's trust, image, and attitude on brand love.
\end{abstract}

Keywords: Brand Trust; Brand Attitude; Social Self; Brand Image; Word of Mouth; Brand Love.

\section{INTRODUCTION}

Consumer satisfaction creates an attitude of the brand and basically, this attitude creates a perception about branding and marketing (Zarantonello, Formisano, \& Grapp, 2016). The literature discusses other brand attributes such as brand trust which is also defined as "the attachment of the brand and belief that it is secure and build on a perception that the brand is durable and provides goodness, fulfils interest of the wellbeing of the consumer” (Huang, 2017). 
The personality reflected by the brand how you are in socially and express the feelings about the brand to the around their people brand creates reflection due to the WOM as cited by (Unal \& Aydin, 2013).

Recent times of young population have a greater opportunity and access to the brands because consumer's thoughts and feelings towards the brands are strong in these eras due to massive information awareness and exposure. Aacording to a researcher, a research study indicated that WOM create stronge perception in the consumer mind about the product and consumer for self satisfaction, self representation and satisfaction belife on that, consequently brand love directly effect on WOM as cited in (Karjaluoto, Munnukka, \& Kiuru, 2016). Relationship of brand with consumer is a contract of the consumer trust with company brand its necessary for the long-term relationship of brand with consumer as cited in (Karjaluoto et al., 2016). Brand image basically maintain an emotional attachment with the product and affect the product marketing concept and also consumers activity as cited by (Cho \& Russell, 2015) Consumer purchases goods on the basis of their preferences which is best and suit on them, the love of brand create on the social circle personality which satisfy due to their brand and that's the reason of the brand likeness and dislikes as cited by (Unal et al, 2013).

\section{STATEMENT OF THE PROBLEM}

Different group of consumers show the effect of brand love. However, difference in standard of class, customer's appearance, customs, values, and their attitude according to the brands and consumer psychology about brand love is highly attached to their product (Unal et al 2013). However, brand love is applicable to any sectors and it is also applicable on different products. Similarly brand love may be caused by any form of consumer like old, male female students etc. on different items of brand love (Chauhan et al., 2013). However, most of the studies corelated the concept of brand love with fast moving consumer good on the bases of developed countreis (Zarantonello, Formisano, \& Grapp, 2016). Thus, to check the postulate of Chauhan et al (2013), this study will explore the concept of brand love with the refernece of consuemr durable goods with respect to Pakistan. This will also bring together the point mentioed by Unal et al (2013) and compose research work from the country which is In developing sides of the world. 


\section{THEORETICAL FRAMEWORK}

Developing countries do not have many studies on brand love same as some researchers discuss this point about brand love and their relationship with the consumer product and their feelings about love (Unal et al, 2013). Future researcher to use the variable brand image as the predictor of brand loves how much effect on brand love (Salam et al 2014). Branding creates exceptional importance, give preference, and show brand lovingness (Hegner, Fenko, \& Teravest, 2017) on the basis of therory of planned behaviour researcher studied the brand attitude contributed the brand love.

On the other side durable product secure and gives trust on product and consumer bond developed with brand and consumer thoughts it is comfortable and satisfy for their product and most important one factor for brand love measure to check brand trust (Huang,et al 2017). Although consumers express their feelings on the basis of satisfaction about the products and its helps to develop the person identity through the brand according to these phenomena create of the WOM and communicate the positive and negative thoughts (Unal et al 2013).

\section{RESEARCH MODEL}

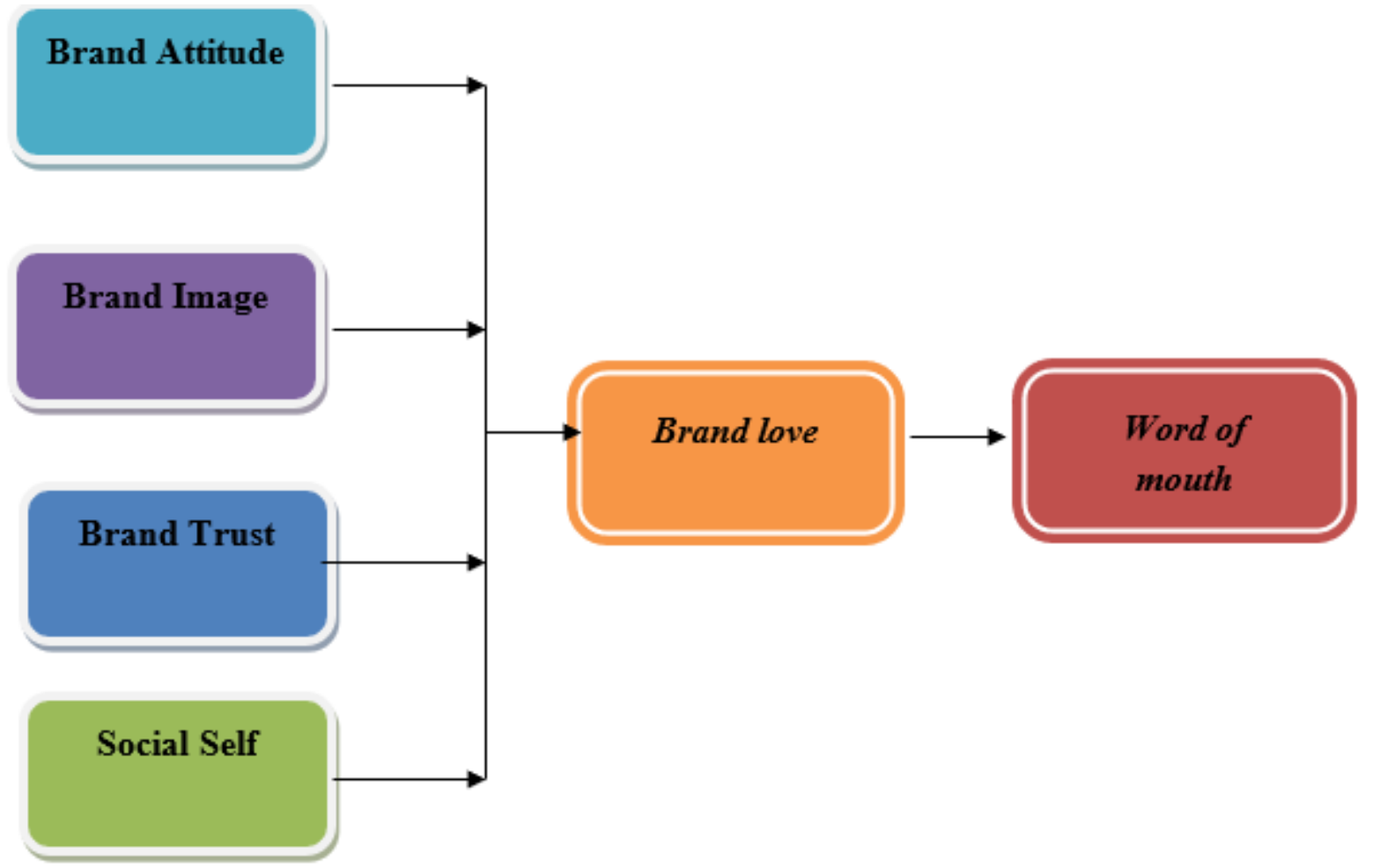




\section{LITERATURE REVIEW}

\section{Brand Attitude and Brand Love}

Zarantonello Formisano, and Grappi (2016) indicated that brand attitude parallel with brand love and it has the strong as well as positive relation. Although previously study indicated that brand attitude is the main factor of brand love and symbol for the brand growth (Batra, Ahuvia,, \& Bagozzi, 2012). In fact, which succeeds in formulating strong attitude to the brand and brands do not bear any cost for advertisement after love of brand therefore (Zarantonello, Formisano, \& Grappi, 2016).

Similar has been indicated by Abhigyan and Abhilash (2012) that attitude of brand is the key element of brand love and both have direct relation with the consumer's purchase behavior. Brand Attitude is the combination of various elements to the consumers mind, and this will increase emotional attachment of customer with the brand (Kim \& Kramer, 2015 \& Rauschnabel \& Ahuvia, 2014).

$\mathrm{H}_{1} \mathrm{~A}$ : There is a relationship between brand attitude and brand love.

\section{Brand Trust and Brand Love}

Huang (2017), investigated that trustworthiness initiatives are the major formulators of brand love (Keller, 2013). Brand trust is the perception of buyer with reliability of brand also satisfied consumer always attract towards their preferable brand as affection elaborated with brand prior studies (Laroche et al., 2012). Study of Sung and Kim (2010) also indicated that the level of love towards brand depends on consumers trustworthy and trust is mainly purpose of repeat purchase habit. Similar has been found by Yusniar, Ruf, Sulaiman, \& Lubis (2017) that brand trust is the main strength of brand love (Fatih, 2013). In fact, trustworthiness associates with the expectations and strongly connects to the brand that leads to high positive outcomes (Hasan et al., 2014).

$\mathrm{H}_{2} \mathrm{~A}$ : There is a relationship between brand trust and brand love.

Brand Image and Brand Love 
Sallam (2014) indicated that brand image have straight relation with brand love in the form of products and service to maintain high image in consumer mind. Good quality of product and service built a strong image in consumer mind and they attract towards brand as love with degree of satisfaction (Leventhal, Wallace, Buil, \& de Chernatony, 2014). Therefore, previous studies e.g. Frikha (2010) Fetscherin et al. (2014) indicated that brand image experiences to brand love by the high and strong connection among brand image $\&$ brand love.

\section{$\mathrm{H}_{3} \mathrm{~A}$ : There is a relationship between brand image and brand love.}

\section{Social Self and Brand Love}

Social self is community plus pursues the support of oriented classification the internal self is secretive plus tails separate connections by brand. Prior studies e.g., Alex and Joseph (2012) and Langner (2015) indicated that social self it has provide single partial proof thus distant around the social self is highly related with brand love in positive direction.

Wallace Buil and Chernatony (2014), indicates that social-self commitment has positively associated with consumer brand affecting as the expression of brand love. Past research studies e.g., Sicilia (2013) and Singh (2012) also give evidence of self-expressive immersion with public self to boost the warmness of consumer's love to brand in particular social atmosphere. In fact, studies like Hollebeek (2014) indicated that brand love related over fit in to social circle of brand on fan page.

\section{$\mathrm{H}_{4} \mathrm{~A}$ : There is a relationship between social self and brand love}

\section{Brand Love and WOM}

Brand love has the positive relation to word of mouth as brand love has the direct and indirect impact on word of mouth (Khamwon, 2016). The phenomena supported by Wallance (2014) that brand love can modified to be used in multicultural environment as it is valuable for modern deal promotion approaches over the good communication about brand. . Brand love has the positive relationship to brand loyalty, and word of Mouth (WOM), and brand loyalty has the positive relationship to WOM. Hence, brand love has a direct and indirect influence on word of mouth through brand loyalty (Maisam \& Mahsa, 2016). However, as per Nejad, Samadi, Tolabi, and 
Pour (2014) and Tuskej Golo and Podnar (2013) that result of brand love on word of mouth is a single method to enhance good WOM in public group socially new advancing in brand developed interest and love of consumer.

$\mathrm{H}_{5} \mathrm{~A}$ : There is a relationship between brand love and word of mouth.

\section{RESEARCH METHODOLOGY}

\section{Research Design}

The philosophy associated with the study is epistemology Saunders et al (2015), as the purpose is knowledge building. The principal approach that have used was Sanity to consider the behavior of consumer (Melnikovas, 2018). Right approach to do this research was "deductive" in category as per the logic which is stated to cerebral moving from common rule to the definite law (Raithatha, 2017). The responses were collected in specific amount of time through structured closed ended questionnaire therefore the time horizon was cross sectional and study setting was non-contrived (Saunders, Lewis \& Thornhill, 2009).

\section{Sampling Design}

Huang (2017) explored the reaction of consumer concerning their love and trust towards electronic goods through non-probability sampling. Similar has been used by Sedgwick, (2013) and Cardinal Zamora Chambers Barrachina and Hough (2015), who preffered convenience sampling for conducting their studies. The type of sampling indicates for data collection was convenient sampling although the method was associated with it was non-probability (Sedgwick, 2013) and was also conduct with convenient sampling while non-probability sampling method. The sample size for the study was approximately 300 as implied by TaherDoost (2017) as well as by Mugenda \& Mugenda (2013).

$$
\begin{gathered}
\text { Sample Size }=\mathrm{Z}^{2} \cdot \mathrm{pq} / \mathrm{e}^{2} \\
\mathrm{n}=(1.96)^{2} *(0.5)(1-0.5)
\end{gathered}
$$




$$
\mathrm{n}=\frac{0.9604}{0.0025} \quad \text { Sample size }=384.16
$$

\section{Research Instrument}

Questionnaire was developed through considering Karjaluoto Munnukka, and Kiuru (2016); Kruger, Kühn, Petzer, and Mostert (2013); Unal and Aydin, (2013) and Wallace Buil and Chernatony (2014).

\section{STATISTICAL TESTING}

\begin{tabular}{|l|l|l|}
\hline & R Square & R Square Adjusted \\
\hline Brand Love & 0.592 & 0.587 \\
\hline WOM & 0.523 & 0.522 \\
\hline
\end{tabular}

Table 1: Quality Criteria (Predictive Accuracy)

\begin{tabular}{|l|l|l|l|l|}
\hline & $\begin{array}{l}\text { Cronbach's } \\
\text { Alpha }\end{array}$ & rho_A & $\begin{array}{l}\text { Composite } \\
\text { Reliability }\end{array}$ & AVE \\
\hline Brand Attitude & 0.886 & 0.888 & 0.921 & 0.744 \\
\hline Brand Image & 0.892 & 0.902 & 0.925 & 0.754 \\
\hline Brand Love & 0.894 & 0.898 & 0.926 & 0.759 \\
\hline Brand Trust & 0.915 & 0.916 & 0.94 & 0.797 \\
\hline Social-Self & 0.875 & 0.879 & 0.915 & 0.73 \\
\hline WOM & 0.901 & 0.903 & 0.931 & 0.772 \\
\hline
\end{tabular}

Table 2: Construct Reliability and Composite Validity 


\begin{tabular}{|l|l|l|l|l|l|l|}
\hline & $\begin{array}{l}\text { Brand } \\
\text { Attitude }\end{array}$ & $\begin{array}{l}\text { Brand } \\
\text { Image }\end{array}$ & $\begin{array}{l}\text { Brand } \\
\text { Love }\end{array}$ & $\begin{array}{l}\text { Brand } \\
\text { Trust }\end{array}$ & $\begin{array}{l}\text { Social- } \\
\text { Self }\end{array}$ & WOM \\
\hline Brand Attitude & & & & & & \\
\hline Brand Image & 0.843 & & & & & \\
\hline Brand Love & 0.724 & 0.713 & & & & \\
\hline Brand Trust & 0.643 & 0.599 & 0.746 & & & \\
\hline Social-Self & 0.808 & 0.685 & 0.643 & 0.658 & & \\
\hline WOM & 0.746 & 0.679 & 0.804 & 0.665 & 0.655 & \\
\hline
\end{tabular}

Table 3: Descrimnant Validity through HTMT

\begin{tabular}{|l|l|l|l|l|l|}
\hline & $\begin{array}{l}\text { Original } \\
\text { Sample } \\
(\mathbf{O})\end{array}$ & $\begin{array}{l}\text { Sample } \\
\text { Mean }(\mathbf{M})\end{array}$ & $\begin{array}{l}\text { Standard } \\
\text { Deviation } \\
(\mathbf{S T D E V})\end{array}$ & $\begin{array}{l}\text { T Statistics } \\
(|\mathbf{O} / \mathbf{S T D E V}|)\end{array}$ & $\begin{array}{l}\text { P } \\
\text { Values }\end{array}$ \\
\hline $\begin{array}{l}\text { Brand Attitude -> Brand } \\
\text { Love }\end{array}$ & 0.161 & 0.168 & 0.078 & 2.062 & 0.041 \\
\hline $\begin{array}{l}\text { Brand Image -> Brand } \\
\text { Love }\end{array}$ & 0.255 & 0.25 & 0.055 & 4.64 & 0.028 \\
\hline Brand Love -> WOM & 0.723 & 0.725 & 0.04 & 17.9 & 0.019 \\
\hline $\begin{array}{l}\text { Brand Trust -> Brand } \\
\text { Love }\end{array}$ & 0.394 & 0.39 & 0.069 & 5.692 & 0.030 \\
\hline Social-Self -> Brand Love & 0.096 & 0.097 & 0.054 & 1.787 & 0.075 \\
\hline
\end{tabular}

Table 4: Path Coefficient (Total Effects)

\section{CONCLUSION AND DISCUSSION}

The researchers in this study have explored the dimensions of brand love through the word of mouth in consumer durable industry through people of middle class and upper middle class. Results indicated that social self does not have any impact on brand love that is consistent with Mueller Melwani and Goncalo (2012). The rejection of social self might be the resultant of lesser social orientation of consumers and thus they may fear to try new things or models of brand that advertised by Facebook, Instagram, and other social websites. Although, investigation imply deep 
sardonicism the findings of study is reliable, and results are consistent with Karami Bozbay and Arghashi (2018) and Huang (2017) etc. Study also indicated that brand love has the direct and indirect influence of word of mouth since positive words of brand entered into the consumer's hearts and they attract to the brand. Therefore, most of studies e.g. Fetcherin \& Heinrich (2014) were estimate the elements of brand love in fashion industries and FMCG sectors which demonstrated the acceptance of consumer's ability to recognize creative ideas of brands.

\section{FUTURE RESEARCH DIMENSIONS}

Lastovicka and Sirianni (2011) indicated that brand features can affect consumer love. Therefore, consumer's characteristics like; behavior, need for emotional impact and affection classes etc. might create remarkable research question expending a quantitative approach. 


\section{REFERENCES}

Abhigyan, S., \& Abhilash, P. (2012). Understanding and measuring romantic brand love. Journal of Customer Behaviour, 11(4), 324-347.

Alex, N. J., \& Joseph, A. (2012). Hedonic Versus Utilitarian Values: The Relative Importance of Real and Ideal Self to Brand Personality and Its Influence on Emotional Brand Attachment. Vilakshan: The XIMB Journal of Management, 9(2).

Batra, R., Ahuvia, A., \& Bagozzi, R. P. (2012). Brand love. Journal of marketing, 76(2), 1-16.

Bozbay, Z., Karami, A., \& Arghashi, V. (2018). The Relationship between Brand Love and Brand Attitude. In 2nd International Conference on Management and Business, Tebriz, Iran (pp. 8-9).

Cardinal, P., Zamora, M. C., Chambers IV, E., Carbonell Barrachina, Á., \& Hough, G. (2015). Convenience sampling for acceptability and CATA measurements may provide inaccurate results: A case study with fruit-flavored powdered beverages tested in Argentina, Spain, and USA. Journal of Sensory Studies, 30(4), 295-304.

Chauhan, K., \& Pillai, A. (2013). Role of content strategy in social media brand communities: a case of higher education institutes in India. Journal of Product \& Brand Management.

Cho, E., \& Russell, D. W. (2015). Validation of a fashion brand image scale capturing cognitive, sensory, and affective associations: Testing its role in an extended brand equity model. Psychology \& Marketing, 32(1), 28-48.

Fatih, G. (2013). The relationship between brand trust, brand affect, attitudinal loyalty, and behavioral loyalty: A field study towards sports shoe consumers in Turkey. International Journal of Marketing Studies, 5(2), 111.

Fetscherin, M., \& Heinrich, D. (2014). Consumer brand relationships: A research landscape.

Fetscherin, M., Boulanger, M., Gonçalves Filho, C., \& Souki, G. Q. (2014). The effect of product category on consumer brand relationships. Journal of Product \& Brand Management.

Frikha, A. (2010). Conflict in purchase decision making within couples. Journal of Islamic Marketing.

Hasan, H., Kiong, T. P., \& Ainuddin, R. A. (2014). Effects of perceived value and trust on customer loyalty towards foreign banks in Sabah, Malaysia. Global Journal of Emerging Trends in e-Business, Marketing and Consumer Psychology, 1(2), 137-153. 
Hegner, S. M., Fenko, A., \& Teravest, A. (2017). Using the theory of planned behaviour to understand brand love. Journal of Product \& Brand Management.

Hollebeek, L. D., (2014). Consumer brand engagement in social media: Conceptualization, scale development and validation. Journal of interactive marketing, 28(2), 149-165.

Huang, C. C. (2017). The impacts of brand experiences on brand loyalty: mediators of brand love and trust. Management Decision.

Karjaluoto, H., Munnukka, J., \& Kiuru, K. (2016). Brand love and positive word of mouth: the moderating effects of experience and price. Journal of Product \& Brand Management.

Keller, K. (2013). Strategic brand management: Global edition. Pearson Higher Ed.

Khamwon, A. (2015, October). Brand love, brand loyalty, and word of mouth: A case of Airasia. In Niyomsart, S., \& Khamwon, A.(2015, October 19-22). Brand Love, Brand Loyalty, and Word of Mouth: A Case of AirAsia. Paper presented at the International Journal of Arts \& Sciences'(IJAS) International Conference for Business and Economics, Rome, Italy.

Kim, H. C., \& Kramer, T. (2015). Do materialists prefer the "brand-as-servant"? The interactive effect of anthropomorphized brand roles and materialism on consumer responses. Journal of Consumer Research, 42(2), 284-299.

Langner, T. (2015). Is it really love? A comparative investigation of the emotional nature of brand and interpersonal love. Psychology \& Marketing, 32(6), 624-634.

Laroche, M., Habibi, M. R., Richard, M. O., \& Sankaranarayanan, R. (2012). The effects of social media-based brand communities on brand community markers, value creation practices, brand trust and brand loyalty. Computers in Human Behavior, 28(5), 1755-1767.

Lastovicka, J. L., \& Sirianni, N. J. (2011). Truly, madly, deeply: Consumers in the throes of material possession love. Journal of Consumer Research, 38(2), 323-342.

Leventhal, R. C., Wallace, E., Buil, I., \& de Chernatony, L. (2014). Consumer engagement with self-expressive brands: brand love and WOM outcomes. Journal of Product \& Brand Management.

Loureiro, S. M. C., Ruediger, K. H., \& Demetris, V. (2012). Brand emotional connection and loyalty. Journal of Brand Management, 20(1), 13-27.

Maisam, S., \& Mahsa, R. D. (2016). Positive word of mouth marketing: Explaining the roles of value congruity and brand love. Journal of Competitiveness, 8(1), 19-37. 
Melnikovas, A. (2018). Towards an explicit research methodology: Adapting research onion model for futures studies. Journal of Futures Studies, 23(2), 29-44.

Mueller, J. S., Melwani, S., \& Goncalo, J. A. (2012). The bias against creativity: Why people desire but reject creative ideas. Psychological science, 23(1), 13-17.

Mugenda, O. M., \& Mugenda, A. G. (1999). Research methods: Quantitative and qualitative approaches. Act's press.

Munir, F. F. A. (2018). Reliability and validity analysis on the relationship between learning space, student's satisfaction and perceived performance using SMART-PLS. International Journal of Academic Research in Business and Social Sciences, 8(1), 775-783.

Raithatha, Y. (2017). Understanding the economic impact terrorism has on the destination decision making: Northern Irish tourists (Doctoral dissertation, Dublin Business School).

Rauschnabel, P. A., \& Ahuvia, A. C. (2014). You're so lovable: Anthropomorphism and brand love. Journal of Brand Management, 21(5), 372-395.

Sallam, M. A. (2014). The effects of brand image and brand identification on brand love and purchase decision making: the role of WOM. International business research, 7(10), 187.

Saunders, M., Lewis, P., \& Thornhill, A. (2009). Research onion. Research methods for business students, 136-162

Sedgwick, P. (2013, October 25). Convenience sampling. BMJ .

Sicilia, M. P. (2013). brand love in virtual communities", 42nd EMAC Annual Conference Proceedings of Lost in Translation: Marketing in an Interconnected World, Istanbul.

Singh, S. (2012). Brand performances in social media. Journal of interactive marketing, 26(4), 189-197.

Song, H., Wang, J., \& Han, H. (2019). Effect of image, satisfaction, trust, love, and respect on loyalty formation for name-brand coffee shops. International Journal of Hospitality Management, 79, 50-59.

Sultan, M. F., \& Khurram, S. (2018). Analyzing the Effect of Outsourcing by SMEs on Company's Performance Moderating Role of Risks Associated with Decision of Outsourcing: Evidence from SMEs operating in Karachi. European Journal of Business \& Management, 10(19).

Sung, Y., \& Kim, J. (2010). Effects of brand personality on brand trust and brand affect. Psychology \& Marketing, 27(7), 639-661. 
Taherdoost, H. (2017). Determining sample size; how to calculate survey sample size. International Journal of Economics and Management Systems, 2.

Tuškej, U., Golob, U., \& Podnar, K. (2013). The role of consumer-brand identification in building brand relationships. Journal of business research, 66(1), 53-59.

Unal, S., \& Aydın, H. (2013). An investigation on the evaluation of the factors affecting brand love. Procedia-Social and Behavioral Sciences, 92, 76-85.

Yusniar, Ruf, J. J., Sulaiman, \& Lubis, P. H. (2017). Some Antecedent of Brand Love toward Customer Loyalty on Automotives Products. International Journal of Trend in Research and Development, 4(6), 278-281.

Zarantonello, L., Formisano, M., \& Grappi, S. (2016). The relationship between brand love and actual brand performance. International Marketing Review.

Zarantonello, L., Formisano, M., \& Grappi, S. (2016). The relationship between brand love and actual brand performance. International Marketing Review. 